\title{
Spatial distribution patterns and causes of decline of three freshwater species with different biological traits (white-clawed crayfish, bullhead, freshwater pearl mussel) : a review
}

\author{
M. Legalle, S. Mastrorillo*, R. Céréghino
}

Ecolab, UMR 5245, Université Paul Sabatier, 118 route de Narbonne, 31062 Toulouse cedex 9, France.

\begin{abstract}
White-clawed crayfish, bullhead, and freshwater pearl mussel are different model organisms in terms of biological traits. Analysing their distribution patterns, habitat demands, and causes of decline may thus help to derive broader frameworks for conservation projects. This paper includes a wide-ranging literature review for these three threatened freshwater animals, then uses general patterns to make suggestions about broader protection measures for freshwater species. Each species has a patchy distribution, from local to broad spatial scales. However, we point out the difficulty to summarise such knowledge, because many variables were not consistently and/or accurately recorded by workers, and because the range of colonised habitats depends on the environmental heterogeneity within study areas. Causes of decline are chiefly related to human activities which modify the biological, chemical, and physical features of the aquatic environment, and can be classified into four types: physical habitat alterations, interspecific interactions, overfishing and poaching, and natural disturbance. By analysing causes of decline and possible actions, we develop seven general trends that could be adopted for a wider array of species. However, protection plans cannot be effective without actual collaborations between river managers, local inhabitants, and authorities. Finally, the re-introduction procedure itself (if needed) depends on the biology of the species under survey, and remains specific. At the same time, further fundamental research is needed to generalise relationships between population and habitat dynamics at different spatial and temporal scales.
\end{abstract}

Keywords: threatened species, freshwater, physical habitat, disturbance, conservation, environmental management, pearl mussel, white-clawed crayfish, bullhead.

\section{Introduction}

Species' distribution is influenced by a large number of environmental factors, such as the geological history of the area (Kontula \& Väinölä 2001), environmental stability (Ward \& Stanford 1979), ecosystem productivity (Lavandier \& Décamps 1984), habitat heterogeneity and suitability (Gorman \& Kar 1978), and competition and predation (Pianka 1978). However, these factors operate at several spatial and temporal scales, e.g., geologic history affects the biogeography of species at a regional scale, whereas physical characteristics of microhabitats may influence local distributions and/or densities (Hastie et al. 2000a, 2000b). During the last decades, there have been many attempts to model the spatial distribution patterns of a number of species with the broader aim to bring out the influence of numerous biotic and abiotic factors, and the way they may act at various spatial

\footnotetext{
* Corresponding author : E-mail: mastrori@cict.fr
}

scales (Morris 1987, Inoue \& Nunokawa 2002). Indeed, under an applied perspective, quantitative characterisations of preferential environments (from local to regional scales) are fundamental bases to the design of management and conservation projects. Such data help ecologists to bring out relatively constant features of preferred habitats (Lobb \& Orth 1991), to assess habitat suitability or alteration in a given area (Raven et al. 1997), and/or to understand patterns of use and partition of space and resources in closely related species (Degerman \& Sers 1993). Many aquatic species were studied as model organisms under this topic. While great emphasis was laid on flagship species (e.g., salmonids, Roussel et al. 1999), other freshwater species have received little or no attention, certainly because of their lack of economic interest (Mastrorillo et al. 1997). Nevertheless, numerous small benthic-dwelling species, which are less mobile, should be more prone to exhibit important relationships with their habitat, and can be relevant models for a broader understanding of the relationships between 
the distribution of populations and individuals, and habitat features. As human actions often result in the destruction or modification of physical and hydraulic habitats, they are threats for aquatic species, which ecological responses depend on their physiological, behavioural and demographic logic.

Amongst threatened aquatic animals, we focused on three species: the freshwater pearl mussel (Margaritifera margaritifera L., Mollusca Unionidae), the white-clawed crayfish (Austropotamobius pallipes Lereboullet, Crustacea Decapoda), and the bullhead (Cottus gobio L., Pisces Cottidae). We selected these three species because : i) they correspond to different model organisms in terms of biological and ecological traits (mobility, longevity, demography, behaviour, foraging...), ii) they are the focus of many conservation studies in the northern hemisphere, and iii) they have colonised very similar habitat types and often coexist within their range. Many factors, closely related to fishing activities and/or destruction of their physical and hydraulic habitats by man, have led to their decline. These animals are listed species in Annex II of the European Community Habitats Directive 92/43/EEC. However, because habitat and/or species surveys are timeand money-consuming, environmental managers and policy makers need general trends that could be adopted for a wide array of species. Through a literature review, we used the three above-mentioned species i) to analyse general trends in the spatial distribution patterns of threatened species at various perception scales (habitat, river, region), ii) to bring out the main causes of species' decline, and iii) to bring out non-specific guidelines likely to help environmental managers to prevent the decline of the river biota.

\section{Spatial distribution patterns at multiple scales}

The white-clawed crayfish, the bullhead, and the freshwater pearl mussel are widespread in the northern hemisphere (Koli 1969, Vigneux 1997, Young et al. 2001), where they have a broad altitudinal zonation (Table 1), and a latitudinal distribution from Spain up to the Polar Circle. In each of these species exhibit a patchy distribution from the local (e.g., a stream section) to the regional scale, and most authors linked such a pattern to their progressive decline (e.g., Pedroli et al. 1991, Alonso et al. 2000, Cochet 2001).

At regional and local scales, the distribution patterns of populations show clear spatial discontinuities. In some countries such as France or Spain, the white-clawed crayfish is one of the most widespread
Decapod Crustacean (Vigneux et al. 1993, Arrignon 1996), but both species distribution and population densities have been drastically reduced during the last decade (Alonso et al. 2000). At the catchment scale, populations are scarce and reduced to marginal areas of stream systems, which are often disconnected from the main stream (García-Arberas \& Rallo 2000). Such observations reveal that some river sections remain more suitable than others in terms of potential shelters, and this pattern was clearly illustrated by differences in crayfish density among neighbouring sites within a stream systems (Daguerre de Hureaux \& Roqueplo, 1981). Within their vast holartic range, pearl mussel populations are more or less distant, and spatially segregated (Hendelberg 1960). Dams and natural obstructions often limit their longitudinal distribution (Neri 2000). At the beginning of the $20^{\text {th }}$ century, Bonnemère (1901) was the first to suggest a decline in French pearl mussel populations. One century later, M. margaritifera was recognised as an endangered species in Europe (Cochet 2001, Young et al. 2001). Throughout Europe, the bullhead has a disrupted spatial distribution (Bomassi \& Brugel 2000, Englbrecht et al. 2000). In Switzerland, it is now considered as rare to very rare into a third of the rivers, and a half of lakes (Pedroli et al. 1991). In Austria, a strong regression was reported by Kainz \& Gollmann (1989).

Reliable information on the optimal habitat conditions of the species to protect is often regarded as essential by environmental managers who wish to improve habitat quality, and literature reviews are commonly used for such purposes (Smith et al. 1996, Diéguez-Uribeondo et al. 1997a). We compiled data from various local studies, in an attempt to summarise present knowledge on the preferential habitats for the three studied species (Table 1). Such synthetic tables based on literature data require a cautious analyse. Table 1 is not exhaustive, primarily because some environmental variables were accurately described by authors (e.g. temperature, elevation, substrate) whereas others were poorly (or not consistently) documented (e.g. stream order, stream width). Because of the patchy distribution of populations, most authors focused on a rather small set of sampling sites within a restricted geographic area. In each work, the reported range of suitable habitats thus depended on the spatial and temporal heterogeneity within the considered area. For example, depth varied from few centimetres to some decimetres among the study areas in Andreasson (1971), Hruška (1992), García-Arberas and Rallo (2000), and we could conclude that the three studied species live in shallow waters. Nevertheless, researchers caught individuals in deeper water, e.g., until $5 \mathrm{~m}$ 
Table 1. Habitat preferences of A. pallipes, C. gobio, et M. margaritifera, drawn from literature data.

\begin{tabular}{|c|c|c|c|}
\hline & A. pallipes & C. gobio & M. margaritifera \\
\hline \multicolumn{4}{|l|}{ Abiotic factors } \\
\hline Bedrock & Calcareous, granite & Calcareous, granite & Granite and gneiss \\
\hline Stream order & $1-3$ & $1-?$ & $2-6$ \\
\hline Altitude range $(\mathrm{m})$ & $100-1520$ & $0-2380$ & $10-1100$ \\
\hline Zonation (Huet, 1959) & Trout area & $\begin{array}{l}\text { Trout area, grayling area, } \\
\text { rarely barbel area }\end{array}$ & Trout area \\
\hline \multicolumn{4}{|l|}{ Habitat structure } \\
\hline Substrate & $\begin{array}{l}\text { Varied (sand, pebbles, } \\
\text { cobbles, rocks, } \\
\text { macrophytes, stumps, } \\
\text { vegetal remains, roots,...): } \\
\text { any potential shelter. }\end{array}$ & $\begin{array}{l}\text { Varied, often coarse, with } \\
\text { great numbers of shelters, } \\
\text { no silt, few macrophytes. }\end{array}$ & $\begin{array}{l}\text { Sand to rocks, } \\
\text { movable substrate, } \\
\text { few macrophytes, } \\
\text { no silt. }\end{array}$ \\
\hline Depth (m) & $>0.05-1.3$ & "shallow" & $0.4-2$ \\
\hline Stream width (m) & $0.5-7$ & ? & ? \\
\hline Current velocity (m/s) & $0.19-1.09$ & $\begin{array}{l}\text { Slow to moderate, } \\
\text { sometimes fast }\end{array}$ & $\begin{array}{l}\text { Slow to flowing with } \\
\text { turbulence }\end{array}$ \\
\hline Context & $\begin{array}{l}\text { Trees, forest, dense } \\
\text { vegetation. }\end{array}$ & Trees & $\begin{array}{l}\text { Forest, grassland on one } \\
\text { side. }\end{array}$ \\
\hline Channel bank structure & $\begin{array}{l}\text { Very structured (holes, } \\
\text { roots), verticals. }\end{array}$ & Hollow & $\begin{array}{l}\text { Structured to very well } \\
\text { structured }\end{array}$ \\
\hline Shaded area & Rather shaded & $20 \%-60 \%$ of shadow & $30 \%-100 \%$ of shadow \\
\hline Sequence & $?$ & Rather riffle & Just after rapids \\
\hline \multicolumn{4}{|l|}{ Physico-chemical factors } \\
\hline Water temperature $\left({ }^{\circ} \mathrm{C}\right)$ & $0.6-24$ & $2-16.5$ & $0-25$ \\
\hline $\mathrm{pH}$ & $6.5-9$ & $7.3-8.3$ & $6-8.6$ \\
\hline Conductivity $(\mu \mathrm{S} / \mathrm{cm})$ & $50-1690$ & $260-630$ & $91-110$ \\
\hline Oxygen & Well oxygenated & $\begin{array}{l}\text { Well oxygenated } \\
(74 \%-104 \%)\end{array}$ & $\begin{array}{l}\text { Well oxygenated } \\
(>9 \mathrm{mg} / \mathrm{l}, 98-131 \%)\end{array}$ \\
\hline Associated fauna & $\begin{array}{l}\text { Trout, bullhead, minnow, } \\
\text { loach. } \\
\text { Invertebrates indicating } \\
\text { good water quality. }\end{array}$ & $\begin{array}{l}\text { Trout, lamprey, minnow. } \\
\text { Invertebrates indicating } \\
\text { good water quality. }\end{array}$ & $\begin{array}{l}\text { Trout. } \\
\text { Fish population often } \\
\text { small. } \\
\text { Invertebrates indicating } \\
\text { good water quality. }\end{array}$ \\
\hline
\end{tabular}

References: A. pallipes: Daguerre de Hureaux \& Roqueplo 1981, Arrignon 1996, Bernardo et al. 1997, Lachat \& Laurent 1987, Roqueplo 1997, Alonso et al. 2000, García-Arberas \& Rallo 2000, Grandjean et al. 2000, Neveu 2000, Reyjol \& Roqueplo 2002. C. gobio: Andreasson 1971, Laurent \& Moreau 1973, Gaudin 1981, Welton et al. 1983, Gaudin \& Caillère 1990, Pedroli et al. 1991. M. margaritifera: Björk 1962, Hruška 1992, Hastie et al. 2000 a b, Cochet 2001, Hendelberg 1960, Moog et al. 1998.

for the pearl mussel in the River Pärlälven (Arctic Sweden) (Hendelberg 1960). Such bias may also be due to inefficient sampling techniques under conditions such as deep water (Smith et al. 1996, Björk 1962). Thus, when summarising species' habitat preferences from literature data, we must acknowledge that the range of suitable habitat conditions increased with the number of considered studies.

\section{Causes of decline}

For each species, all studies quoted in this paper emphasised the prominent role of man activities in the decline or extinction of populations (Table 2). Degradation of environment and alteration of habitats (both physical and chemical) is the chief factor for population decline, whatever the species. Alteration of the 
Table 2. Main identified reasons for the decline of studied species (quoted from the most to the less important).

\begin{tabular}{lll}
\hline Austropotamobius pallipes & Cottus gobio & Margaritifera margaritifera \\
\hline $\begin{array}{l}\text { Introduction of exotic species: } \\
\text { - exclusion by competition, }\end{array}$ & $\begin{array}{l}\text { Degradation of environment and } \\
\text { alteration of habitats (physical and } \\
\text { - disease mortality. }\end{array}$ & $\begin{array}{l}\text { Degradation of environment and } \\
\text { alteration of habitats (physical and } \\
\text { chemical). }\end{array}$ \\
$\begin{array}{l}\text { Degradation of environment and } \\
\text { alteration of habitats (physical and } \\
\text { chemical). }\end{array}$ & Natural causes (parasitism). & Overfishing. \\
$\begin{array}{l}\text { Poaching and overfishing. } \\
\text { Natural causes (drought, disease). }\end{array}$ & Host fish disappearance. \\
\hline $\begin{array}{l}\text { References: A. pallipes: Holdich 1991, Arrignon 1996, Smith et al. 1996, Bernardo et al. 1997, Diéguez-Uribeondo et al. 1997b, Holdich and } \\
\text { Rogers 1997, Roqueplo 1997, Vigneux 1997, Temiño and Sáez-Royuela 1998, Alonso et al. 2000. M. margaritifera: Bonnemère 1901, } \\
\text { Hendelberg 1960, Björk 1962, Bauer 1983, Hruška 1992, The UK Biodiversity Steering Group 1995, Vaughn and Taylor 1999, Neri 2000, } \\
\text { Cochet 2001, Cosgrove and Hastie 2001, Hastie and Cosgrove 2001. C. gobio: Pedroli et al. 1991, Utzinger et al. 1998, Bomassi and Brugel } \\
\text { 2000, Moravec F. 2001. }\end{array}$ &
\end{tabular}

biotic environment is the second cause of decline, and includes introduction of alien competitors (particularly in crayfish) or removal of host species (pearl mussel). Finally, natural factors, such as drought, floods, or parasitism have the lowest impact, compared to human-induced threats. These causes of decline are further detailed below, and can be classified into the four following groups.

\section{Habitat alteration}

Channel banks structure, riparian vegetation (tree species and quantity), and waterside soil use are key factors to the success of populations in stream species. As any action increasing banks and land erosion may be lethal to some populations (e.g., cattle overgrazing, extensive deforestation, stamping), a dense riparian vegetation strip may allow to reduce detrimental effects. Indeed, roots provide refuge habitats (Smith et al. 1996) and strengthen banks (Abernethy \& Rutherfurd 2000), and vegetation density reduces the access to the river. Moreover, vegetation strips between streams and adjacent lands have a buffer effect as they temporarily retain scoured nutrients (Tabacchi et al. 2000). Some tree species are more suitable than others, e.g., alder (Alnus sp.), willow (Salix sp.), and hazel tree (Corylus avellana) (Smith et al. 1996). Conversely, some tree species are detrimental to the aquatic biota, e.g., riparian conifers acidify the stream environment, and their culture have been reported to cause the decline of pearl mussel populations (The UK Biodiversity Steering Group 1995).

As a major human influence, river regulation is known to adversely affect physical and hydraulic habitats. It pri- marily leads to a decrease in the abundance of potential shelters, either by increasing river competence (sensu Minshall 1984) and substrate instability (Cobb et al. 1992), or by reducing stream flow and increasing water depth so that concentrations of suspended matters increase (Bomassi \& Brugel 2000). For example, sediment size and stability are a crucial prerequisite to allow colonisation and persistence by pearl mussel (Williams et al. 1993 , Di Maio \& Corkum 1995), but siltation and accumulation of plant detritus due to reduced flow may lead mussel populations to extinction (Hendelberg 1960, Hastie et al. 2000a). Several authors reviewed the impact of river regulation with emphasis on the effects of flow regimes on the habitat of aquatic organisms (Brittain \& Saltveit 1989, Gore et al. 1989, 1994, Kinsolving \& Bain 1993, Moog 1993). They chiefly reported that: i) increased flow constancy reduced the average number of taxa, although mean density may increase in some species, and ii) widely fluctuating daily flows and current velocities lead to lower benthic densities and richness, whereas population structure is usually modified (Crisp 1993), with the youngest life stages being the most affected. Indeed, when flow patterns are artificial, unpredictable variations may cause a strong mortality in the critical development stages (Poff et al. 1997), e.g., larval and juveniles stages of freshwater mussels were observed to be removed by high current velocity before individuals established their territories (Holland-Bartels 1990, Layzer \& Madison 1995).

Chemical alterations are caused by direct or diffuse pollution by human activities at the catchment scale (e.g. sewage disposals, extensive agriculture, fertilisers, industrial practices...) (Bomassi \& Brugel 2000). They 
usually induce the decline of populations by reducing individual fecundity and/or growth. An example can be quoted for each studied species. In pearl mussels, slight eutrophication inhibit the growth of young individuals and increase mortality from $10 \%$ to $70 \%$ in older mussel (Bauer et al. 1980, Bauer 1983). In bullheads, agricultural and industrial pollutants cause residual accumulations in fish tissues, which adversely affect fecundity and may cause sterility, or even the death of organisms (Bomassi \& Brugel 2000). Finally, strong and sudden mortality of crayfish was often explained by alterations of the chemical environment (excessive phosphate and nitrate concentrations, heavy metals) (Holdich \& Rogers 1997). Moreover, weakened crayfish under poor chemical conditions are much more sensitive to pathogenic bacteria (Roqueplo \& Daguerre de Hureaux 1983, Arrignon 1996).

\section{Interspecific interactions}

Exotic species were introduced for aquacultural (high productivity, rapid growth and high fecundity), culinary, and aquarist purposes (Holdich \& Rogers 1997, Laurent 1997). Coexistence with alien species chiefly affects native species through competition for refuge habitats (Vorburger \& Ribi 1999). Introduced species usually grow faster, have a greater size and less restricted habitat requirements than native species (Holdich \& Rogers 1997). Such ecological advantages are detrimental to the partition of habitat and food resource, and native populations may rapidly decline to extinction. Moreover, foreign species may be predators to native species, and/or may be vectors of diseases (Diéguez-Uribeondo et al. 1997b). This problem chiefly affected the white-clawed crayfish. The introduction of exotic crayfish species (Astacus leptodactylus Eschscholtz, Orconectes limosus Rafinesque, Pacifastacus leniusculus Dana, Procambarus clarkii Girard) was the main reason for the decline of A.pallipes in Europe (Laurent 1997), as it led to a competitive exclusion of native crayfish, and brought the crayfish plague caused by the fungus Aphanomyces astaci (Diéguez-Uribeondo et al. 1997b). A. pallipes populations which were subjected to introduced predatory crayfish could only subsist in colder sections of headwater streams, i.e., where exotic species where unable to withstand the colder thermal conditions (Gil-Sánchez \& Alba-Tercedor 2002).

The decline of bullhead populations is certainly not caused by interspecific competition. Cottus gobio commonly coexists with other fish species (chiefly salmonids and loach) with no or little competitive interactions (Jørgensen et al. 1999, Welton et al. 1983). Coexistence is allowed by resources partitioning (mainly food and shel- ters), and certainly favoured by the behavioural and morphological characteristics of this fish species (Welton et al. 1991, Gaudin \& Caillère 1990, 2000, Gabler et al. 2001). However, bullhead's distribution and density at a site was reported to be significantly influenced by the presence of predators such as the pike (Esox lucius L.) or the burbot (Lota lota L.) in Swedish rivers (Degerman \& Sers 1994), or by the presence of competitors / predators such as signal crayfish (P. leniusculus) in British rivers (Guan \& Wiles 1997).

To complete its life cycle, the freshwater pearl mussel uses salmonid fish as hosts for its glochidia larvae. In Europe, the most suitable host seems to be brown trout (Salmo trutta L.) and salmon (Salmo salar L.), with preference for youngest stages (Young \& Williams 1984a, 1984b). American studies of freshwater mussels concluded that the decline of some populations was due to changes in fish community, and specifically to the disappearance of the appropriate fish host (Haag \& Warren 1998, Vaughn \& Taylor 1999). It is very likely that the decline of the freshwater pearl mussel in Europe is partially due to the regression of host fish populations (Hastie \& Cosgrove 2001). Moreover, very high losses are linked to the random meeting between larva and fish, and then between larva and suitable substratum (Björk 1962, Young \& Williams 1984a). Finally, the restocking of salmonid reaches with non-native salmonids such as rainbow and brook trout is a potential threat to the long-term survival of freshwater pearl mussels, as they may out-compete the native species and are not suitable hosts for glochidia (Young \& Williams 1984a, 1984b)

\section{Overfishing and poaching}

Species such as white-clawed crayfish and freshwater pearl mussel were particularly subjected to overfishing and poaching, because of their economical interest (gastronomy, jewellery). The capture of spawners, even when their size is below the legal size of capture (Roqueplo 1997), adversely affects the renewal rate of populations, which is particularly detrimental to species with slow growth. As the survival of freshwater pearl mussel depend on host fish availability, the overfishing of the European salmonids populations may be an indirect threat to M. margaritifera (Chesney \& Oliver 1998, Cosgrove et al. 2000).

\section{Natural disturbance}

Mortality due to natural disturbance is scarce, but may drastically affect some populations. During strong drought periods, desiccation causing death of individuals in high numbers was observed for freshwater pearl 
mussels (Björk 1962) and white-clawed crayfish (Holdich 1991, Temiño \& Sàez-Royuela 1998). Similarly, individuals may die from desiccation or asphyxiation caused by subsiding of floods (Hruška 1992, Neri 2000). A mass mortality was thus observed in a crayfish population after heavy summer rainfalls (Almaça 1990). Over-density of crayfish populations is known to increase mortality by disease. For example, the porcelain disease seems to be density-dependent (Brown \& Bowler 1977, Smith et al. 1996).

\section{A general conservation framework}

By considering the well-known causes of decline and operational means, we summarized some possible management options in Table 3. Beyond its synthetic contents, Table 3 clearly shows that i) rehabilitating a population cannot work without a rehabilitation of habitat conditions, and ii) any proposed action (and therefore any protection plan) cannot be effective without actual collaborations between river managers, local human populations, and authorities. Regardless to the considered species, protection measures will be first designed to preserve the spatial and temporal heterogeneity of stream habitats. Even if a given species has completely disappeared in the area, habitat improvement (e.g. before a reintroduction project) will favour those species associated with good water and habitat quality (e.g. benthic insects). By using the literature backgrounds highlighted in this paper, we attempted to design a framework for restoration-protection projects, whatever the considered species. This framework could be made of the following steps:

1 - map the current distribution of populations in the area under survey, estimate their number, their density and their demographic status (declining, viable, young, recently settled).

2 -map the spatial distribution and assess the density of competitor populations (e.g. introduced competitors).

3 - A thorough knowledge of optimal habitat conditions of the considered species is essential in order to protect and/or to improve the habitat quality: make a literature review on this topics for species under survey. Then, with respect to species ecological requirements, classify suitable areas as protected zones.

4 - Sustain viable populations by limiting access to their environment, and temporarily or definitively restrict their exploitation (Reynolds 1997).

5 - Support declining populations with reintroduction, create new population in potentially suitable environment by adding individuals (Holdich \& Rogers 1997,
Alonso et al. 2000). Genetic characteristics have to be considered: reasoning by autochtonous stocking is probably more suitable than by autochtonous species (Vigneux 1997).

6 - Continue surveys of existing and/or reintroduced populations to adapt management options to the success of populations: find explanations of reintroduction failure, continue actions if a population increases.

7 - Increase public information and awareness about populations, and measures to be respected to allow their preservation. Restoration plans can work correctly, but only if the various social and economic actors collaborate efficiently.

Unlike preventive actions and general conservation measures, deriving global reintroduction patterns is a difficult task. Reintroduction procedures are closely linked to the biology of considered organisms, and thus remain specific. Some examples are given hereafter. Moog et al. (1998) suggested to reintroduce M. margaritifera by using glochidia-infected fish in a suitable area, and to support existing populations with artificial infections of host fish. This method was widely accepted since the beginning of the $20^{\text {th }}$ century (Coker et al. 1919-20). More recently, the culture of juvenile freshwater pearl mussels in cages offered promising reintroduction prospects (Buddensiek 1995). The introduction of juveniles A. pallipes (about 16 months old) seems to be the best compromise between breeding cost and survival rate in the introduction area (Arrignon 1996, Vigneux \& Vigneux 1981). Because of the high risk of diseases such as the crayfish plague, most European countries suggested a health control of crayfish populations under survey. Introduction of bullhead by man was first reported in 1979 in Fennoscandia (River Utjoski) (Pihlaja et al. 1998), and, nowadays, bullheads seem to have spread into other neighbouring streams (Jørgensen et al. 1999). Therefore, the introduction of bullheads in suitable environments seems to be feasible, either from wild or farming populations (rearing C. gobio in fish tank is quite easy (Gaudin 1981)). Artificial substratum were also used to preserve and expand populations (Knaepkens et al. 2002).

Given the physical and chemical alterations in rivers throughout the world, and subsequently the alteration of aquatic biodiversity, preventive actions for the protection of freshwater habitats are urgently required. Although our literature review focused on three selected species, it allowed us to point out some general considerations about the conservation of threatened aquatic species and their preferential habitats. At broad spatial scales, the decline of a species can be perceived when only small 
Table 3. Summary of adverse conditions to bullhead, white-clawed crayfish, and pearl mussel populations, and possible actions to improve their suitable habitat.

\begin{tabular}{|c|c|c|c|}
\hline Adverse conditions & Main causes & Consequences for the species & Considered actions \\
\hline Peak flows & $\begin{array}{l}\text { Hydroelectric } \\
\text { facilities }\end{array}$ & $\begin{array}{l}\text { Catastrophic drift, mortality, to } \\
\text { the detriment of early instars }\end{array}$ & $\begin{array}{l}\text { Artificial fluctuations should remain } \\
\text { within the amplitude of seasonal } \\
\text { variations. }\end{array}$ \\
\hline $\begin{array}{l}\text { Reduced flow, clogged } \\
\text { substrate (siltation, fine } \\
\text { particulate organic } \\
\text { matters...) }\end{array}$ & $\begin{array}{l}\text { Natural obstacles } \\
\text { (e.g., dead trees), } \\
\text { dams }\end{array}$ & $\begin{array}{l}\text { Destruction of suitable } \\
\text { habitats, fragmentation, } \\
\text { longitudinal discontinuities, } \\
\text { limitation of upstream / } \\
\text { downstream migrations }\end{array}$ & $\begin{array}{l}\text { Remove stocks and dead trees. If } \\
\text { considered, dredging should } \\
\text { preserve habitat suitability }\end{array}$ \\
\hline $\begin{array}{l}\text { Eutrophication, toxic } \\
\text { substances (e.g., } \\
\text { insecticides, heavy } \\
\text { metals...) }\end{array}$ & $\begin{array}{l}\text { Wastewater and/ } \\
\text { or urban and/or } \\
\text { agricultural } \\
\text { runoff }\end{array}$ & $\begin{array}{l}\text { Inhibited growth, mortality, } \\
\text { decreased fecundity, sterility }\end{array}$ & $\begin{array}{l}\text { Improve collecting system of } \\
\text { wastewater, plantation/maintenance } \\
\text { of a dense riparian vegetation } \\
\text { (retention of the nutriments, buffer } \\
\text { zone). Favourable species: alder, } \\
\text { hazel tree, willow }\end{array}$ \\
\hline Acidification & Riparian conifers & Mortality & $\begin{array}{l}\text { Replace trees by favourable species } \\
\text { (see above) }\end{array}$ \\
\hline $\begin{array}{l}\text { Introduction of exotic } \\
\text { species }\end{array}$ & $\begin{array}{l}\text { Halieutic } \\
\text { production, } \\
\text { aquarist purposes }\end{array}$ & competition, predation, disease & Destruction \\
\hline Capture of spawners & $\begin{array}{l}\text { Overfishing, } \\
\text { poaching }\end{array}$ & $\begin{array}{l}\text { Decreased population turnover } \\
(+ \text { destruction of river banks })\end{array}$ & $\begin{array}{l}\text { Increased surveillance? } \\
\text { Legislation? } \\
\text { Limit access to the stream with a } \\
\text { dense riparian vegetation in } \\
\text { sensitive reaches }\end{array}$ \\
\hline Asphyxiation & Natural drought & Mortality & $\begin{array}{l}\text { Surveillance of sensitive streams, } \\
\text { eventually translocation of } \\
\text { individuals to the remaining } \\
\text { suitable habitats }\end{array}$ \\
\hline
\end{tabular}

populations remain with a patchy distribution, increasing the risk of endemism. At local scales, the causes of decline are chiefly related to the neighbouring human activities which modify the biological, chemical, and physical features of the aquatic environment. Many biomonitoring techniques use classifications of reference sites from rivers of high biological quality to provide site-specific predictions of the fauna to be expected under undisturbed conditions, using a small set of environmental characteristics (Naura \& Robinson 1998, Wright et al. 2000, Hastie et al. 2003). By knowing what the ecosystem should be like in a given geographic zone, ecologists can thus determine the degree to which human activity has altered it. However, our review suggests that further fundamental research is still needed to generalise relationships between population (hatching success, life cycle and growth patterns, production) and habitat (e.g., spatial and temporal fluctuations of suitable microhabitats vs. flow patterns) dynamics at different spatial and temporal scales (Resh \& Rosenberg 1989). Finally, if a great attention was given to some species (e.g., A. pallipes, M. margaritifera), the will to protect other threatened species is relatively recent, and we will probably need more time for a proper view of the success and failures of conservation plans.

\section{Acknowledgements}

This work was funded by the French Ministry of Environment, the French Water Agency (Agence de l'Eau Adour-Garonne), Regional Councils of Regions Auvergne and Midi-Pyrénées, and General Councils of Lot and Cantal (grant $\mathrm{N}^{\circ}$ 02.33.023). We thank A. Compin (Ecolab), A. David (AAVL, Figeac), and S. Dupetitmagneux (Maurs) for their technical assistance. 


\section{References}

Abernethy B. \& Rutherfurd I.D. 2000. - The effect of riparian tree roots on the mass-stability of riverbanks. Earth Surf. Proc. Land., 25, 921-937.

Almaça C. 1990. - Recursos animais e sua conservaçao : as populaçoes portuguesas do lagostim-de-rio, Astacus pallipes Lereboullet, 1858. Museu Nacional de História Natural, 3, 22.

Alonso F., Temiño C. \& Diéguez-Uribeondo J. 2000. - Status of the white-clawed crayfish, Austropotamobius pallipes (Lereboullet, 1858), in Spain: distribution et legislation. Bulletin Français de la Pêche et de la Pisciculture 356, 17-30.

Anderson N. H 1 Cummins K. W. 1979. - Influence of diet on the life histories of aquatic insects. J. Fish. Res. Board Can.,36, 335-342.

Andreasson S. 1971. - Feeding habits of a bullhead (Cottus gobio L. Pisces) population. Report of the Institute of Freshwater Research Drottningholm 51, 5-30.

Arrignon J. 1996. - L'écrevisse et son élevage, $3^{\text {rd }}$ ed. Lavoisier Tec $\&$ Doc, Paris.

Bauer G. 1983. - Age structure, age specific mortality rates and population trend of the freshwater pearl mussel (Margaritifera margaritifera) in North Bavaria. Arch. Hydrobiol., 98, 523-532.

Bauer G., Schrimpff E., Thomas W. \& Herrmann R. 1980. Zusammenhänge zwischen dem Bestandsrückgang der Flußperlmuschel (Margaritifera margaritifera) im Fichtelgebirge und der Gewässerbelastung. Arch. Hydrobiol., 88, 505-513.

Bernardo J. M, Ilhéu M. \& Costa A. M. 1997. - Distribution, population structure and conservation of Austropotamobius pallipes in Portugal. Bull. Fr. Peche. Piscic., 347, 617-624.

Björk S. 1962. - Investigations on Margaritifera margaritifera and Unio crassus. Acta Limnologica 4, 1-109.

Bomassi P. \& Brugel C. 2000. - L'état des connaissances sur les populations en Auvergne des espèces de l'ichtyofaune inscrites à l'annexe 2 de la directive "habitats". Conseil Supérieur de la Pêche, Délégation Régionale Auvergne, Lempdes, France.

Bonnemère L. 1901. - Les mollusques des eaux douces de France et leurs perles. Institut International de Bibliographie scientifique, Paris.

Brittain J. E. \& Saltveit S. J. 1989. - A review of the effect of river regulation on Mayflies (Ephemeroptera). Regul. Riv. Res. Manage., 3, 191-204.

Brown D. J. \& Bowler K. 1977. - A population study of the British freshwater crayfish Austropotamobius pallipes (Lereboullet). Freshwat. Crayfish, 3, 33-49.

Buddensiek V. 1995. - The culture of juvenile freshwater pearl mussels Margaritifera margaritifera $\mathrm{L}$. in cages: a contribution to conservation programmes and the knowledge of habitat requirements. Biol. Cons., 75, 33-40.

Chesney H. C. G. \& Oliver P. G. 1998. - Conservation issues for Margaritiferidae in the British Isles and Western Europe. pp. 231-242 In: Molluscan Conservation. A strategy for the 21 st Century (eds I. Killeen \& A. M. Holmes). Journal of Conchology Special Publication $\mathrm{N}^{\circ} 2$.

Cobb D. G., Galloway T. D. \& Flannagan J. F. 1992. - Effects of discharge and substrate stability on density and species composition of stream insects. Can. J. Fish. Aquat. Sci., 49, 1788-1795.

Cochet G. 2001. - La moule perlière, une espèce en chute. Revue de l'agence de l'eau Adour Garonne 82, 13-17.

Coker R. E., Shira A. F., Clark H. W. \& Howard A. D. 1919-20. Natural history and propagation of freshwater mussels. Bull. US Bur. Fish., 893, 76-181.
Cosgrove P. J. \& Hastie L. C. 2001. - Conservation of threatened freshwater pearl mussel populations, river management, mussel translocation and conflict resolution. Biol. Cons., 99, 183-190.

Cosgrove P. J., Hastie L. C. \& Young M. R. 2000. - Freshwater pearl mussels in peril. Brit. Wild.,11, 340-347.

Crisp D. T. 1993. - Population densities of juvenile trout (Salmo trutta) in five upland streams and their effects upon growth, survival and dispersal. J. Appl. Ecol., 30, 759-771.

Daguerre de Hureaux N. \& Roqueplo C. 1981. - Définition du biotope préférentiel de l'écrevisse à pattes blanches, Austropotamobius pallipes (Ler.) dans un ruisseau landais. Bull. Fr. Peche. Piscic.281, 211-222.

Degerman E. \& Sers B. 1994. - The effect of lakes on the stream fish fauna. Ecol. Freshwat. Fish, 3, 116-122.

Di Maio J. \& Corkum L. D. 1995. - Relationship between the spatial distribution of freshwater mussels (Bivalvia: Unionidae) and the hydrological variability of rivers. Can. J. Zool., 73, 663-671.

Diéguez-Uribeondo J., Rueda A., Castien E. \& Bascones J. C. 1997a. - A plan of restoration in Navarra for the native freshwater crayfish species of Spain, Austropotamobius pallipes. Bull. Fr. Peche. Piscic.347, 625-637.

Diéguez-Uribeondo J., Temiño C. \& Muzquiz J. L. 1997b. - The crayfish plague fungus in Spain. Bull. Fr. Peche. Piscic.347, 753-763.

Englbrecht C. C., Freyhof J., Nolte A., Rassmann K., Schliewen U. \& Tautz D. 2000. - Phylogeography of the bullhead Cottus gobio (Pisces: Teleostei: Cottidae) suggests a pre-Pleistocene origin of the major central European populations. Mol. Ecol., 9, 709-722.

Gabler H. M., Amundsen P. A. \& Herfindal T. 2001. - Diet segregation between introduced bullhead (Cottus gobio L.) and Atlantic salmon parr (Salmo salar L.) in a sub-Arctic river. Arch. Hydrobiol., 151, 609-625.

García-Arberas L. \& Rallo A. 2000. - Survival of natural populations of Austropotamobius pallipes in rivers in Bizkaia, Basque Country (North of Iberian Peninsula). Bull. Fr. Peche. Piscic.356, 17-30.

Gaudin P. 1981. - Eco-éthologie d'un poisson benthique, le chabot, Cottus gobio L. (Cottidae): distribution, alimentation et rapports avec la truite, Salmo trutta L. PhD Thesis, University Claude-Bernard, Lyon, France.

Gaudin P. \& Caillère L. 1990. - Microdistribution of Cottus gobio L. and fry of Salmo trutta L. in a first order stream. Polsk. Arch. Hydrobiol.,37, 81-93.

Gaudin P. \& Caillère L. 2000. - Experimental study of the influence of presence and predation by sculpin, Cottus gobio L., on the drift of emergent brown trout, Salmo trutta L. Arch. Hydrobiol., 147, 257-271.

Gil-Sánchez J. M. \& Alba-Tercedor J. 2002. - Ecology of the native and introduced crayfishes Austropotamobius pallipes and Procambarus clarkii in southern Spain and implications for conservation of the native species. Biol. Cons., 105, 75-80.

Gore J. A., Nestler J. M. \& Layzer J. B. 1989. - Instream flow predictions and management options for biota affected by peaking-power hydroelectric operations. Regul. Riv. Res. Manage., 3, 35-48.

Gore J. A., Niemela S., Resh V. H. \& Statzner B. 1994. Near-substrate hydraulic conditions under artificial floods from hydropower operation: a preliminary analysis of disturbance intensity and duration. Regul. Riv. Res. Manage., 9, 15-34.

Gorman O. T. \& Kar J. R. 1978. - Habitat structure and stream fish communities. Ecology, 59, 507-515.

Grandjean F., Cornuault B., Archambault S., Bramard M. \& Otrebsky G. 2000. - Life history and population biology of the 
white-clawed crayfish, Austropotamobius pallipes pallipes, in a brook from the Poitou-Charentes region (France). Bull. Fr. Peche. Piscic.356, 55-70.

Guan R. Z. \& Wiles P. R. 1997. - Ecological Impact of Introduced Crayfish on Benthic Fishes in a British Lowland River. Conserv. Biol.,11, 641-647.

Haag W. R. \& Warren M. L. Jr. 1998. - Role of ecological factors and reproductive strategies in structuring freshwater mussel communities. Can. J. Fish. Aquat. Sci., 55, 297-306.

Hastie L. C. \& Cosgrove P. J. 2001. - The decline of migratory salmonid stocks: a new threat to pearl mussels in Scotland. Freshwat. Forum, 15, 85-96.

Hastie L. C., Boon P. J. \& Young M. R. 2000a. - Physical microhabitat requirements of freshwater pearl mussels, Margaritifera margaritifera (L.). Hydrobiologia, 429, 59-71.

Hastie L. C., Young M. R., Boon P. J., Cosgrove P. J. \& Henninger B. 2000b. - Sizes, densities and age structures of Scottish Margaritifera margaritifera (L.) populations. Aquat. Conserv. Mar. Fresh. Ecosyst., 10, 229-247.

Hastie L. C., Cooksley S. L., Scougall F., Young M. R., Boon P. J. \& Gaywood MJ. 2003. - Characterization of freshwater pearl mussel (Margaritifera margaritifera) riverine habitat using River Habitat Survey data. Aquat. Conserv. Mar. Fresh. Ecosyst., 13, 213-224.

Hendelberg J. 1960. - The fresh-water pearl mussel, Margaritifera margaritifera (L.). Report of the Institute of Freshwater Research Drottningholm, 41, 149-171.

Holdich D. M. 1991. - The native crayfish and threats to its existence. Brit. Wild., 2, 141-161.

Holdich D. M. \& Rogers W. D. 1997. - The white-clawed crayfish, Austropotamobius pallipes, in Great Britain and Ireland with particular reference to its conservation in Great Britain. Bull. Fr. Peche. Piscic.347, 597-616.

Holland-Bartels L. E. 1990. - Physical factors and their influence on the mussel fauna of a main channel border habitat of the upper Mississippi River. J. N. Amer. Benthol. Soc., 9, 327-335.

Hruška J. 1992. - The freshwater pearl mussel in South Bohemia : Evaluation of the effect of temperature on reproduction, growth and age structure of the population. Arch. Hydrobiol., 126, 181-191.

Huet M. 1959. - Profiles and biology of western European streams as related to fish management. Trans. Amer. Fish. Soc., 88, 155-163.

Inoue M. \& Nunokawa M. 2002 - Effects of longitudinal variations in stream habitat structure on fish abundance : an analysis based on subunit-scale classification. Freshwat. Biol., 47, 1594-1607.

Jørgensen L., Amundsen P. A., Gabler H. M., Halvorsen M., Erkinaro J. \& Niemelä E. 1999. - Spatial distribution of Atlantic salmon parr (Salmo salar L.) and bullhead (Cottus gobio L.) in lotic and lentic habitats of a diversified watercourse in northern Fennoscandia. Fisheries Res., 41, 201-211.

Kainz E. \& Gollmann H. P. 1989. - Beiträge zur Verbreitung einiger Kleinfischarten in österreichischen Fließgewässern. Oesterreichs Fischerei, 42, 204-207.

Kinsolving A. D. \& Bain M. B. 1993. - Fish assemblage recovery along a riverine disturbance gradient. Ecol. Appl.,s 3, 531-544.

Knaepkens G., Bruyndoncx L., Bervoets L. \& Eens M. 2002. - The presence of artificial stones predicts the occurrence of the European bullhead (Cottus gobio) in a regulated lowland river in Flanders (Belgium). Ecol. Freshwat. Fish, 11, 203-206.

Koli L. 1969. - Geographical variation of Cottus gobio L. (Pisces, Cottidae) in Northern Europe. Ann. Zool. Fenn., 6, 353-390.
Kontula T. \& Väinölä R. 2001. - Postglacial colonization of Northern Europe by distinct phylogeographic lineages of the bullhead, Cottus gobio. Mol. Ecol., 10, 1983-2002.

Lachat G. \& Laurent P. J. 1987. - The habitat of Astacus astacus L. and Austropotamobius pallipes Lere. in the Morvan. Freshwat. Crayfish, 7, 61-68.

Laurent P. J. 1997. - Introductions d'écrevisses en France et dans le monde, historique et conséquences. Bull. Fr. Peche. Piscic., 344/ $345,345-356$.

Laurent M. \& Moreau G. 1973. - Influence des facteurs écologiques sur le coefficient de condition d'un téléostéen (Cottus gobio L.). Ann. Hydrobiol.,4, 211-228.

Lavandier P. \& Décamps H. 1984. - Estaragne. In: Ecology of European rivers (ed. B.A. Whitton) pp. 237-264. Blackwell Scientific Publications, Oxford.

Layzer J. B. \& Madison L. M. 1995. - Microhabitat use by freshwater mussels and recommendations for determining instream flow needs. Regul. Riv. Res. Manage.,10, 329-345.

Lobb M. D. \& Orth D. J. 1991. - Habitat use by an assemblage of fish in a large warmwater stream. Trans. Amer. Fish. Soc., 120, 65-78.

Mastrorillo S., Lek S., Dauba, F. \& Belaud A. 1997. - The use of artificial neural networks to predict the presence of small-bodied fish in a river. Freshwat. Biol., 38, 237-246.

Minshall G. W. 1984. - Aquatic insect-substratum relationships. pp 358-400 In: The ecology of aquatic insects (eds V. H. Resh \& D. M. Rosenberg). Praeger Publishers, New York.

Moog O. 1993. - Quantification of daily peak hydropower effects on aquatic fauna and management to minimize environmental impacts. Regul. Riv. Res. Manage., 8, 5-14.

Moog O., Ofenböck T., Nesemann H. \& Stundner C. 1998. - The freshwater pearl mussel Margaritifera margaritifera (L.) in Austria: Fundamental conservation measures for an endangered species. Verh. Internat. Verein. Limnol., 26, 2438-2443.

Moravec F. 2001. - Common sculpin Cottus gobio as a natural paratenic host of Proteocephalus longicollis (Cestoda: Proteocephalidae), a parasite of salmonids, in Europe. Dis. Aquat. Organisms, 45, 155-158.

Morris D. W. 1987. - Ecological scale and habitat use. Ecolog,y 68, 362-369.

Naura M. \& Robinson M. 1998. - Principles of using River Habitat Survey to predict the distribution of aquatic species : an example applied to the native white-clawed crayfish Austropotamobius pallipes. Aquat. Conserv. Mar. Fresh. Ecosyst., 8, 515-527.

Neri F. 2000. - Présence de Margaritifera margaritifera (Linnaeus 1758) (Mollusca: Bivalvia: Margaritiferidae) dans les monts de Lacaune (Tarn) et le Sommail (Hérault). Vertigo 7, 59-61.

Neveu A. 2000. - Etude des populations d'Austropotamobius pallipes (Crustacea, Astacidae) dans un ruisseau forestier de Normandie. II. Répartition en fonction des habitats: stabilité et variabilité au cours de cinq années. Bull. Fr. Peche. Piscic., 356, 99-122.

Pedroli J. C., Zaugg B. \& Kirchhofer A. 1991. - Atlas de distribution des poissons et cyclostomes de Suisse. Centre Suisse de cartographie de la faune: Neuchâtel, Suisse (Switzerland).

Pianka E. R. 1978. - Evolutionary ecology. $2^{\text {nd }}$ Edition. Harper and Row, New York.

Pihlaja O., Niemelä E. \& Erkinaro J. 1998. - Introduction and dispersal of the bullhead, Cottus gobio L., in a subarctic salmon river in northern Finland. Fish. Manage. Ecol., 5, 139-146.

Poff N. L., Allan J. D., Bain M. B., Karr J. R., Prestegaard K. L., Richter B. D., Sparks R. E. \& Stromberg J. C. 1997. - The natural flow regime. BioScience, 47, 769-784. 
Raven P. J., Fox P., Everard M., Holmes N. T. H. \& Dawson F. H. 1997. - River Habitat Survey: a new system for classifying rivers according to their habitat quality. pp. 215-234 In: Freshwater quality: defining the indefinable? (eds P. J. Boon \& D. L. Howell). The Stationery Office, Edinburgh.

Resh V. H. \& Rosenberg D. M. 1989. - Spatial-temporal variability and the study of aquatic insects. Can. Entomol., 121, 941-963.

Reyjol Y. \& Roqueplo C. 2002. - Répartition des écrevisses à pattes blanches, Austropotamobius pallipes (Lereboullet, 1858), dans trois ruisseaux de Corrèze; observation particulière des juvéniles. Bull. Fr. Peche. Piscic., 367, 1-19.

Reynolds J. D. 1997. - The present status of freshwater crayfish in Ireland. Bull. Fr. Peche. Piscic., 347, 693-700.

Roqueplo C. 1997. - Etude de populations d'écrevisses à pattes blanches (Austropotamobius pallipes Lereboullet) en cours d'eau, soumises à une pêche de loisir. L'Astaciculteur de France 51, 59-70.

Roqueplo C. \& Daguerre de Hureaux N. 1983. - Etudes de populations naturelles d'écrevisses (A. pallipes) dans le Sud-Ouest de la France. CEMAGREF, Etude n ${ }^{\circ} 14$, France.

Roussel J. M., Bardonnet A. \& Claude A. 1999. - Microhabitat of brown trout when feeding on drift and when resting in a lowland salmonid brook: effects on Weighted Usable Area. Arch. Hydrobiol., 146, 413-429.

Smith G. R. T., Learner M. A., Slater F. M. \& Foster J. 1996. Habitat features important for the conservation of the native crayfish Austropotamobius pallipes in Britain. Biol. Cons., 75, 239-246.

Tabacchi E., Lambs L., Guilloy H., Planty-Tabacchi A. M., Muller E. \& Décamps H. 2000. - Impacts of riparian vegetation on hydrological processes. Hydrol. Proc.,14, 2959-2976.

Temiño C. \& Sáez-Royuela C. 1998. - Resumen de los inventarios de cangrejo autóctono Austropotamobius pallipes realizados en la provincia de Burgos entre 1984 y 1997. Internal report of the Servicio Territorial de Medio Ambiente de Burgos, Burgos, Spain.

The UK Biodiversity Steering Group. 1995. - Biodiversity: The UK Steering Group Report - Volume II : action plans. Annex G: Species action plans, habitat action plans and habitat statements. HMSO, London.

Utzinger J., Roth C. \& Peter A. 1998. - Effects of environmental parameters on the distribution of bullhead Cottus gobio with particular consideration of the effects of obstructions. J. Appl. Ecol.,35, 882-892.
Vaughn C. C. \& Taylor C. M. 1999. - Impoundments and the decline of Freshwater Mussels: a case study of an extinction gradient. Conserv. Biol., 13, 912-920.

Vigneux E. 1997. - Les introductions de crustacés décapodes d'eau douce en France. Peut-on parler de gestion ? Bull. Fr. Peche. Piscic., 344/345, 357-370.

Vigneux D. \& Vigneux E. 1981. - Gestion des peuplements astacicoles - Repeuplements. Bull. Fr. Peche. Piscic., 281, 169-184.

Vigneux E., Keith P. \& Noël P (eds). 1993. - Atlas préliminaire des Crustacés Décapodes d'eau douce de France. Collection Patrimoines Naturels, vol. 14. SFF, IBMM-MNHN, CSP, Ministère de l'Environnement, Paris.

Vorburger C. \& Ribi G. 1999. - Aggression and competition for shelter between a native and an introduced crayfish in Europe. Freshwat. Biol., 42, 111-119.

Ward J. V. \& Stanford J. A. 1979. - Ecological factors controlling stream zoobenthos with emphasis on thermal modification of regulated streams. pp. 35-55 In: The ecology of regulated streams (eds J. V. Ward \& J. A. Stanford). Plenum Press, New York.

Welton J. S., Mills C. A. \& Pygott J. R. 1991. - The effect of interaction between the stone loach Noemacheilus barbatulus (L.) and the bullhead Cottus gobio (L.) on prey and habitat selection. Hydrobiologia, 220, 1-7.

Welton J. S., Mills C. A. \& Rendle E. L. 1983. - Food and habitat partitioning in two small benthic fishes, Noemacheilus barbatulus (L.) and Cottus gobio L. Arch. Hydrobiol., 97, 434-454.

Williams J. D., Warren M. L. Jr., Cummings K. S., Harris J. L. \& Neves R. J. 1993. - Conservation status of freshwater mussels of the United States and Canada. Fisheries 18, 6-22.

Wright J. F., Sutcliffe D. W. \& Furse M. T. (eds). 2000. - Assessing the biological quality of fresh waters: RIVPACS and other techniques. Freshwater Biological Association, Ambleside, UK.

Young M. R. \& Williams J. 1984a. - The reproductive biology of the freshwater pearl mussel Margaritifera margaritifera (Linn.) in Scotland. I. Field studies. Arch. Hydrobiol., 99, 405-422.

Young M. R. \& Williams J. 1984b. - The reproductive biology of the freshwater pearl mussel Margaritifera margaritifera (Linn.) in Scotland. II. Laboratory studies. Arch. Hydrobiol., 100, 29-43.

Young M. R., Cosgrove P. J. \& Hastie L. C. 2001. - The extent of, and causes for, the decline of a highly threatened naiad: Margaritifera margaritifera. pp. 337-357 In: Ecology and Evolutionary Biology of the Freshwater Mussels Unionoidea (eds G. Bauer \& K. Wachtler K). Springer Verlag, Berlin. 